sexual pleasure, in or out of marriage, with femaleor male-might be enjoyed.

Indeed, had Damon and Lycidas not sported with but married Amaryllis and Neaera, the men might have found helps meet for their becoming better shepherds/poets and more worthy candidates for the celestial chorus - as long, that is, as neither let the tangles of his hair be shorn by his bride. Men are "the perfecter sex," Milton maintains in $A n$ Apology (695) and elsewhere, and must uphold their authority in marriage. But sexual union in marriage he declares pure, and he condemns those who "[d]efam[e] as impure what God declares / Pure, and commands to some, leaves free to all" (Paradise Lost 4.746-47). Milton's discomfort in and out of "Lycidas" is not with female sexuality but with female domination.

Kenneth Alan Hovey University of Texas, San Antonio

Reply:

I had hoped someone would challenge my essay by citing Milton's remarks on defilement in the Apology, and so I'm grateful to Kenneth Alan Hovey for giving me the opportunity to expand on this matter. While the ensuing comments necessarily emphasize the points on which we differ, I believe we are closer to agreement than might at first appear. I respect the thoroughness of his scholarship and the general moderation of his rhetoric.

Hovey's primary objection to my article involves its use of Revelation 14.3-4 to express discomfort with the possibility of feminine defilement. Citing the Apology and The Geneva Bible, Hovey argues to the contrary that this passage refers exclusively to fornication and cannot therefore be taken as evidence that Milton considered women to be a defilement "in themselves" (i.e., apparently, in wedlock).

Unfortunately, Hovey's evidence works against him. Note that the Geneva gloss to which he refers identifies the defilement of Revelation 14 "chiefly [as] idolatrie which is the spiritual whoredome" (my italics). As it happens, this is the lapse of which the Son convicts Milton's Adam in book 10 of Paradise Lost: "Was [Eve] thy God that her thou didst obey / Before his voice[?]" (10.146-47). By conceiving the defilement of Revelation 14 as primarily a spiri- tual rather than a carnal phenomenon, Milton by no means excludes it from the purview of wedlock; on the contrary, he makes an exegetical choice that will eventually lead him to identify such defilement as the original marital error.

From this standpoint it would appear to be Hovey, not I, who adopts an excessively literal reading of Revelation 14, a reading consonant with his apparent unwillingness to consider defilement as anything other than sexual relations and sexual relations as anything other than physical congress. Milton knew better, as a glance at the divorce tracts will make clear.

Nor does it follow, as Hovey seems to think, that because female contact may defile, therefore female contact must defile-any more than it follows that a fear of female defilement must lead one to exclude the ladies of the Maske and of sonnets 9, 14, and 19 from heaven on the basis of their gender. It is Hovey, not I, who describes women as "innately defiling," and I'm not overjoyed that he should attribute the phrase to me or to my view of Milton. What I do say-although Hovey overlooks it—is that Milton's verse expresses both "a longing for connubial union" (228) and "a concurrent aversion to feminine defilement" (231); again, just to make the point clear, I remark that Milton's sense of matrimony in "Lycidas" is "conflicted," in keeping with the anxieties embodied in the poet's later writing on marriage in general (233). Apparently Hovey dislikes such ambivalence and would prefer to see me promote an unconflicted, uncompromisingly misogynist view of the poet. Alas, I do not.

Bruce Boehrer Florida State University

\section{Kristeva and Derrida}

\section{To THE EDITOR:}

I was disappointed to read, in her interview with Alison Rice ("Forgiveness: An Interview" [117 (2002): 281-95]), Julia Kristeva's literal paraphrase of Jacques Derrida's thought on forgiveness: "Derrida dit en substance que, si on s'engage dans une réflexion sur le pardon et dans une pratique correspondant à cette réflexion, il faudrait pardonner l'impardonnable [...]" 'Derrida says that if one engages in this reflection on forgiveness and its practice, it 